\title{
Isichazamazwi SesiNdebele as Reflector of the Moral and Ideological Values of Society*
}

Nobuhle Moyo, African Languages Research Institute (ALRI), University of Zimbabwe, Harare, Zimbabwe (nobumoyo@arts.uz.ac.zw)

\begin{abstract}
Isichazamazwi SesiNdebele (henceforth the ISN) reflect the moral and ideological values of society. This article analyses the ISN as reflector of the moral and ideological values of the Ndebele society. The ISN highlights fundamental beliefs and ideas of the Ndebele people. The study stems from the observation that the culture of a people will always reflect in a dictionary as culture and language are inextricably intertwined. The aim of this article is to discuss the ways in which the ISN reflects the moral and ideological values of society. The article examines how the society in which the dictionary was created influenced the choice of lemmas and the phrasing of definitions. The focus is on sexist definitions, terms referring to ethnic groups and the treatment of taboo words and religious terms. These terms denote cultural attitudes harboured by the Ndebele society. The article discusses how the treatment of these terms reflects on the values prevalent in the culture of the Ndebele community.
\end{abstract}

Keywords: MONOLINGUAL DICTIONARY, DEFINITIONS, LANGUAGE, CULTURE, TABOO WORDS, IDEOLOGICAL VALUES, SEXIST ATTITUDES

Opsomming: Isichazamazwi SesiNdebele as reflekteerder van die morele en ideologiese waardes van die gemeenskap. Isichazamazwi SesiNdebele (voortaan die ISN) weerspieël die morele en ideologiese waardes van die gemeenskap. Hierdie artikel ontleed die ISN as reflekteerder van die morele en ideologiese waardes van die Ndebelegemeenskap. Die ISN belig fundamentele beskouings en opvattings van die Ndebelevolk. Die studie spruit voort uit die waarneming dat die kultuur van 'n volk altyd in 'n woordeboek weerspieël sal word omdat kultuur en taal onlosmaaklik vervleg is. Die doel van die artikel is om die maniere te bespreek waarop die ISN die morele en ideologiese waardes van die gemeenskap reflekteer. Die artikel ondersoek hoe die gemeenskap waarin die woordeboek tot stand gekom het die keuse van lemmas en die bewoording van definisies beïnvloed het. Die fokus is op seksistiese definisies, terme wat na etniese groepe verwys en die behandeling van taboewoorde en godsdienstige terme. Hierdie terme dui kulturele ingesteldhede aan wat deur die Ndebelegemeenskap gekoester word. Die artikel bespreek hoe die behandeling van hierdie terme waardes reflekteer wat in die kultuur van die Ndebelesamelewing gangbaar is.

* This article was presented as a paper at the Tenth International Conference of the African Association for Lexicography, organized by the Sesiu sa Sesotho National Lexicography Unit, University of the Free State, Bloemfontein, Republic of South Africa, 13-15 July 2005.

Lexikos 17 (AFRILEX-reeks/series 17: 2007): 349-359 
Sleutelwoorde: EENTALIGE WOORDEBOEK, DEFINISIES, TAAL, KULTUUR, TABOEWOORDE, IDEOLOGIESE WAARDES, SEKSISTIESE INGESTELDHEDE

\section{Introduction}

Lexicography is a discipline which exhibits an extensive interconnection between language and culture. Goodenough (1974: 36) points out that "a society's culture consists of whatever it is one has to know or believe in order to operate in a manner acceptable to its members". Isichazamazwi SesiNdebele (henceforth the ISN) reflects those cultural aspects that guide the behaviour of members of the Ndebele society. According to Algeo (1990: 2006-2007), "the dictionary can be used as a means of access to the values of the society: it can give a reasonably accurate idea of what is valued, or on the contrary stigmatized" in a particular society. As such the selection and definition of terms in the ISN reflects cultural aspects that are either prized or denounced among the Ndebele. As an authority on usage, the dictionary highlights the social acceptability of certain terms. It can therefore be argued that culture defines the standards of conduct through the language. According to the Whorfian hypothesis, a people's mother tongue offers them a framework for their perception of the world. Thus, while it is imperative in lexicography to know about words and their meanings, there is also a need to know about attitudes, manners and social norms. This might be termed the cultural competence of an individual in general and the lexicographer in particular. Gregerson (1977: 156) states that "language can be studied not only with reference to its formal properties ..., but also with regard to its relationship to the lives and thoughts and culture of the people who speak it". Pride and Holmes (1986: 9-10) echoes similar sentiments:

Any individual member of a community must acquire far more than the formal or structural features of his language(s). He must undergo a process of socialization; he must acquire a knowledge of the social and cultural values of his society, the constraints which the society imposes on behaviour - including language behaviour.

In the light of this statement, it can be said that language forms an important part of a people's definition of life. Through analysing the choice of lemmas and phrasing of definitions, this article aims at discussing the ways in which the ISN reflects the moral and ideological values of the Ndebele society. Focus will be on the treatment of terms displaying the class structure of the Ndebele which include sexist definitions and reference to ethnic groups. The presentation of taboo and religious words will also be discussed. Conforming to a set of beliefs that form the basis of a social system has, however, implications for lexicography in general. This is usually realised in the treatment of "offensive" words where the lexicographer is caught between being forthright and being euphemistic (Chabata and Mavhu 2005) all in the name of upholding the culture of a society. 


\section{Choice of entries}

The choice of entries in the ISN was guided by the frequency-list distribution in the Ndebele corpus. Words lemmatised are those mostly found in the corpus, therefore showing evidence of wide use in both spoken and written Ndebele. The written form of the language, central to language and culture promotion, becomes a permanent source of reference for future generations. In the compilation of a dictionary, a lexicographer therefore has to take cognizance of various cultural aspects, which include certain norms and beliefs embodied in a language. Since language and culture share a complementary relationship, the language used in the dictionary, and the ISN in particular, depicts the worldview of the Ndebele people. What is of significance to this article is the treatment of various entries in the dictionary which will be discussed in relation to the moral and ideological values prevalent in the society.

\section{Class structure in Ndebele society}

Fromkin and Rodman (1993: 303) mention that the words used to refer to certain individuals or groups reflect "individual non linguistic attitudes" and may also reflect "the culture and views of the society". In Ndebele, various terms indicate the attitudes the society holds against certain individuals. These usually include terms referring to women in general and certain ethnic groups. Thus language is seen as harbouring certain social values promoted by dictionaries, which are repositories of the whole culture. The way the ISN denotes sexist and ethnic attitudes implied by terms and definitions referring to women and foreigners will be discussed in the following two sections.

\subsection{Sexist definitions}

Kunene and Mulder (1992: 336) point out that "siSwati cultural views about women are reflected throughout the language of siSwati grammar, lexical items and phrases used in everyday speech". This is also true of the Zimbabwean context, in particular among the Ndebele. The entries and definitions in the ISN play a part in the localising and maintaining of women in disadvantaged positions. The language therefore connotes sexist attitudes, which are values in the society. Words referring to certain individuals or certain groups are a reflection of the cultural views of the society because the culture of any society is expressed in its language. Fromkin and Rodman (1993: 312) highlight this:

Just as the use of some words may reflect society's views towards sex or natural body functions or religious beliefs, some words may also reflect racist, chauvinist and sexist attitudes in society.

In Ndebele culture, women, in comparison with men, are usually presented in an unfavourable light. This attitude is reflected in the language. For example: 
imitha bz 5. Imitha ngowesifazane osewake wazala engendanga. (This is a woman who has given birth outside of marriage.)

The definition reflects how Ndebele culture views unmarried women who become pregnant. It carries a derogatory tone since the woman is already viewed negatively on account of her physical condition while the man on the other hand is free to behave at pleasure. In addition to this, the noun imitha is derived from the verb -mitha (conceive) used in reference to animals, which furthermore conveys a negative view of such a woman. The reason for this treatment is to uphold the traditional view of a woman's morality. Again, a woman whose marriage has failed is referred to as isaliwakazi, because society regards her as the offender. Conditions that led to the break-up of the marriage are not considered both ways. The man is not called by an equivalent term to describe his morals. The word is entered as follows in the dictionary:

isaliwakazi bz 7. Isaliwakazi ngumuntu wesifazane owehlukana lomkakhe. (A divorcee is a woman who separated from her husband.)

It carries the notion that it is the woman who divorced the man, not the other way round. Women are thus seen as inferior members of society who have to live within certain parameters set by society. These views are reflected by the dictionary. While women's negative attributes are overemphasized, men's negative attitudes are championed. Thus in Ndebele society there is an idiom which says indoda yinja (a man is a dog), meaning that it is not surprising for a man to have a number of women as wives. It is the society which instills these values, every individual being socialized into believing that men are unique members of society who are at liberty to behave at pleasure, while women are set certain measures which restrict their existence in society.

Another of these words which reflects society's view of women is isifebe (prostitute) defined as follows in the ISN:

isifebe bz 7. [...] 2 Isifebe ngumuntu wesifazana othethweyo oba lobudlelwano bensitha labesilisa angendelanga kubo. [...] (A prostitute is a married woman who involves herself in private relationships with males to whom she is not married.)

The word feba (commit adultery) is defined in a similar way:

-feba sz gmwa. Ukufeba yikuwula komuntu wesifazane owendileyo. (This is when a married woman commits adultery.)

The definitions of these words imply that it is only females who behave in a manner unacceptable to society. Men, however, go without chastisement. This cultural attitude towards women indicates male sexist prejudices about women reflected in the language. This sexist language shows that Ndebele culture expects women to behave according to a different and more restrictive code than 
men. These cultural views of women evident in the language are also reflected in a lexicographical product.

There are many other names used to describe the conditions in which women find themselves while men on the other hand are not depicted by similar appellations. This points to an ideology in society which is constantly watching the behaviour of women. Thus they are given names in accordance with their physical conditions.

Language tends to reflect sexism in paired words which usually carry some often-noticed overtones. According to Fasold (1993: 113), these words are supposedly semantically equivalent except that the one refers to male and the other to female. The Ndebele language demonstrates that these words have different associations which are reflective of the sexist attitudes of society. For example, in Ndebele an unmarried woman is referred to as umazakhela (literally: one who builds for herself) while a bachelor is referred to as insumbelume. They are entered as follows in the ISN:

umazakhela bz 1a. Umfazi othiwa ngumazakhela ngosekhulile ongendanga, kumbe owatshiya umendo wazakhela owakhe umuzi. (A spinster is an old unmarried woman or a divorcee living by herself.)

insumbelume bz 9. Insumbelume ngumuntu wesilisa osedlule ibanga lokuthatha kodwa elokhu engelamfazi. ( $A$ bachelor is a man who is past the rightful age of marrying but is still unmarried.)

In these cases, Fasold (1993: 113) observes that a bachelor is seen as unmarried by choice and living happily, while a spinster conjures the image of an old, unappealing woman living an unfulfilled life in consequence of her failure to marry, hence the need to fend for herself as reflected by the literal meaning of the Ndebele word umazakhela. This also shows that Ndebele society believes that "motherhood is the highest goal of traditional African woman" (Lippert 1972: 166), which can only be achieved in marriage. The language used in the ISN reflects these sexist views and values of a male-dominated society.

The sexist values of Ndebele society are also shown in entries where women are given names on account of their physical conditions. For example, the term inyumba is defined as follows:

inyumba bz 9. Inyumba ngumuntu wesifazane ongazaliyo. ( $A$ barren woman is one who has failed to conceive.)

Biology has proven that it is not only women who are barren, as African societies like the Ndebele tend to believe. However, since it is the staunch belief of Ndebele society that only women can be barren, women, not men, bear the negative name. This prejudice of a patriarchal society where women receive the blame results in the stereotyping of women. The ISN thus expresses the ideology of society.

The presentation of Ndebele women in the ISN also indicates the status 
society accords them. In general, women have always been relegated to subordinate positions in African societies and this also applies in Ndebele society. It is these underlying societal values that result in the negative depiction of women. The dominance of patriarchal ideology grants a privileged status to males in comparison with females. In Ndebele society, it is therefore not expected to find a man who is unsuccessful in life. Thus such a man is termed indunayabafazi (chief of the women), which appears in the ISN as follows:

indunayabafazi bz 9. 1 Indunayabafazi ngumuntu wesilisa ongasumuntu walutho. [...] ( 1 A chief of women is a very useless man. [...])

This indicates the inferior status accorded women in Ndebele society. An unsuccessful man is not only termed a chief (someone with power and authority) but also named in accordance with his superiority over women. This stems from the general patriarchal belief that women cannot be successful in life.

\subsection{Ethnic groups}

Fasold (1987: 148) observes that "attitudes towards language are often the reflection of attitudes towards members of various ethnic groups". This is also evident in the Ndebele language. During the pre-colonial period, the Ndebele community was socially divisive. Those associated with the royal family of the (abeZansi) Ndebele state enjoyed a high and prestigious social status. The Ndebele language used in the ISN thus mirrors the divisions among the Ndebele community. People not originally Nguni are referred to as amahole implying their inferior status as compared to the original Ndebeles from Zululand. This superiority complex in Ndebele culture is reflected in the language and therefore also in the dictionaries. The word ihole is defined as follows:

ihole bz 5. Ihole ligama lokuthuka ingqe ngumuntu ongasimzansi ngokudabuka. Akulunganga ukulisebenzisa kwabanye abantu. (This is an insulting term used to refer to anyone who is not Nguni by origin. It is not proper to use this term to refer to other people.)

This word is used to mock anyone who is not of Nguni ethnic origin. The definition shows that ihole is insulting under all circumstances. This kind of attitude is a result and a manifestation of the underlying values and beliefs which constitute a community's culture. Pride and Holmes (1986: 9) observe that an individual member of a community must acquire knowledge of the cultural values of his society and the constraints which the society imposes on behaviour, including language behaviour.

Similar to ihole are the words inyasarandi (one who originates from Malawi) and iTshabi (one who is not Ndebele by origin) which have the following definitions: 
inyasarandi bz 5. Inyasarandi ligama elithukayo lomuntu odabuka eMalawi. (This is an insulting term referring to someone who originates from Malawi.)

iTshabi bz 5. Leli ligama lokweyisa elisetshenziswa ngamaNdebele limele wonke umuntu onsundu ongasiNdebele ngomdabuko. (This is a pejorative term used by Ndebeles to refer to anyone who is not Ndebele by origin.)

The above words and definitions reflect the values prevalent among the Ndebele people. Thus different ethnic groups were given names in accordance with their attitudes towards the group. Therefore language attitudes generally reflect ideological or cultural differences among the different ethnic groups. A lexicographer becomes a reflector of the culture expressed by a particular language. The language used in the dictionary therefore mirrors the ideology of the society by which it is spoken.

\section{Taboo words}

Fromkin and Rodman (1993: 303) are of the view that dictionaries often give clues to social attitudes. In Ndebele culture, certain qualities are vested in the language making it possible to comment on certain situations when using proper discourse. For example, it is taboo among the Ndebele directly to refer to $u k u f a$ (death of a king). It can only be expressed in euphemistic terms. Nyathi (2001: 124) says: "When a king dies, it is said 'the mountain has fallen' intaba idilikile. Sometimes ... 'he has bowed down' inkosi isikhotheme." For in Ndebele culture, it is considered disrespectful to say umuntu ufile (a person has died). Instead, it is said a person has passed away (usedlule) or has sunk (usetshonile). This shows that death is a taboo subject among the Ndebele, therefore making it unacceptable to refer to it directly. The lexicographer has to be sensitive to this cultural attitude.

As mentioned earlier, a people's mother tongue offers them a framework for their perception of the world. In many cultures and that of the Ndebele in particular, it is also taboo directly to refer to terms with sexual connotations, as becomes evident from dictionaries. In these cultures, reference to such terms must be done euphemistically. Similarly their treatment in dictionaries is in accordance with what the society expects. Although taboo words were entered in the ISN because of their presence in the Ndebele corpus, the phrasing of the definitions clearly indicates that it is against the social norms of the Ndebele to define them explicitly. Doing so will be a violation of the moral code of conduct on the part of the lexicographers. As a way of upholding the cultural values of the Ndebele people, the editors of the ISN defined these terms in a polite manner. For example the definition of the word igolo (vagina) reads as follows:

igolo bz 5 Igolo yisitho sensitha sowesifazana esixhumanisa isibeletho lezitho zensitha ezingaphandle. Ligama elihloniphisayo leli. (The vagina 
is a female private body part attached to the womb and other private parts on the outside. The term is impolite.)

In this definition, euphemistic expressions like yisitho sensitha (private part) are used to explain this word. The definition points out that ligama elihloniphisayo meaning 'the term' should be used with prudence. An explicit definition which could have defined the word in terms of its function in childbearing or sexual intercourse is unacceptable in Ndebele culture. Hence the definition reflects the Ndebele moral values. Another definition treated in a similar manner is the word ubolo (penis) defined as follows:

ubolo bz 11. Ubolo yisitho sendoda kumbe inyamazana enduna esisetshenziswa ukuchema kumbe ukwandisa uhlobo. (The penis is a part of the body of a male being or animal that is used for urinating as well as increasing the species.)

In this example, the word ubolo (penis) is defined only in terms of its use in conception and urination. The euphemistic expression ukwandisa uhlobo is meant to fit the definition into the acceptable cultural norms of the Ndebele. This shows that lexicographers have a specific mandate to use language acceptable to the society, because language is inextricably bound up with the culture of a people. Chabata and Mavhu (2005: 255) concur that "the lexicographer's pen is sometimes not free to write its owner's views and convictions". Thus the lexicographer is forced to write in a manner reflecting the sensitivities of the society for whom the dictionary is intended. Another example which supports this point is the way the back matter of the ISN is presented. The back matter covers a variety of cultural information which includes, among others, the names of different body parts. While most of the parts have been entered, those referring to the private parts have deliberately been omitted. However, as shown above, these words have been defined in the central list of the dictionary in a manner acceptable to the society when dealing with taboo words. Lexicographers as members of the society simply conform to a set of beliefs that form the basis of their social system.

\section{Religious words}

Religious words too are associated with the belief system of the Ndebele. Nyathi (2001: 4) observes that "it becomes very difficult, in fact, impossible, to isolate religion from other aspects of Ndebele culture". The ISN indicates that the Ndebele society basically believes in two types of religion, namely the traditional African religion and Christianity. Various terms relating to both the traditional African and Christian beliefs are entered in the dictionary.

The culture of a society contains all the beliefs that a society has about itself. In traditional Ndebele culture, amadlozi (ancestors) are viewed as a source 
of livelihood for the family. The basis of Ndebele religion lies in the belief in ancestral spirits. Generally the life of the Ndebele centres on the recognition and appeasement of the ancestors to solicit more protection and blessings from them. The definition of amadlozi reads as follows in the ISN:

amadlozi bz 6. Amadlozi yimimoya yabantu asebafayo okukholelwa ukuthi iyaphenduka izelondoloza kumbe ukuphazamisa impilo zabaphilayo. (Ancestors are the spirits of the dead believed to come back either to take care of the living or to disturb their lives.)

The use of the word okukholelwa indicates that it is not easy to arrive at the underlying values or beliefs in ancestors, hence it recognizes the fact that not everyone in Ndebele society believes in or has faith in ancestral spirits. For someone who strongly believes in the propitiation of the ancestors, these values are highly recognized. The fact that the definition is not authoritative might not satisfy those who believe in the ancestral religious practice. However, the tone of the definition seeks to strike a balance with those who believe in other religious practices, further highlighting the differing values within Ndebele society.

In the same way, the word $u$ Nkulunkulu is defined as follows in the ISN:

uNkulunkulu bz 1a. UNkulunkulu kukholelwa ukuthi ngumdali wezinto zonke emhlabeni [...] (God is believed to be the creator of everything on earth.)

This example also shows that it is difficult to make the definition authoritative, because it refers to something that cannot be proven. However, Christians might feel that the definition does not accord God the rightful status as it carries the notion of impossibility of proof. The Random House College Dictionary (1988) enters God in this way:

God $[\ldots]$ the Supreme Being, the creator and ruler of the universe.

This definition, in contradistinction to the one in the ISN, expresses the indisputability of God's part in the existence of the universe. Perhaps this difference stems from the history of Christianity among the Africans in general and the Ndebele in particular. Before the advent of Christianity, the Ndebele used to communicate with God via the ancestors and some still do even today. However, the introduction of Christianity among the Africans brought with it some negative views on beliefs in the traditional ancestral religion. In a 2003 interview with Hadebe, the editor-in-chief of the ISN, he pointed out that in defining most of these terms associated with the belief systems of the Ndebele, the editors felt that Pelling in his bilingual English-Ndebele dictionary had suppressed the African religion, thus they had to shed more light on it when defining words associated with it. For example, Pelling (1971) enters the word isangoma in the following way: 
is-angoma $[\ldots]$ witch doctor.

This definition presents isangoma (spirit medium) in an unfavourable, derogatory light where an association with witchcraft is implied. It reflects the belief of Christians that the spirit medium is inspired by the devil. However, because some Ndebeles believe in spirit mediums, it is entered in a different manner, with no undertones of witchcraft, in the ISN. In sharp contrast to Pelling's definition, it is presented as follows:

isangoma bz 7. Isangoma ngumuntu oledlozi lobungoma njalo okuvumisayo. (A spirit medium is a person who possesses the spirit of the ancestors which helps in diagnosis.)

Unlike Pelling, who describes isangoma as a witch doctor, this definition connects it with the belief in ancestral spirits. Not everyone in Ndebele culture is a Christian, therefore words pertaining to both belief systems of the Ndebele should be entered and defined explicitly in the dictionary, the reason being that a dictionary's greatest value is to give access to the full range of a language. The ISN therefore mirrors the various religious beliefs in Ndebele society.

\section{Conclusion}

This article has discussed the different ways in which language reflects the moral and ideological values of a society. As the reflectors of the culture of a people, lexicographers are compelled to be truly descriptive and exactly explain what the words mean in a given society. While this is achievable with other word categories, taboo subjects have always constrained lexicographers into conforming to a set of beliefs forming the basis of a social system. As a result taboo words are dealt with in a manner that does not arouse controversy in a specific society. This obviously has implications for lexicography as a discipline that considers meaning as central. However, this clearly shows how the culture of a society permeates into all spheres of life including dictionary compilation.

\section{References}

Algeo, J. 1990. American Lexicography. Hausmann, F.J. et al. (Eds.). 1989-1991. Wörterbücher. Ein internationales Handbuch zur Lexikographie / Dictionaries. An International Encyclopedia of Lexicography / Dictionnaires. Encyclopédie internationale de lexicographie: 1987-2009. Berlin: Walter de Gruyter.

Chabata, E. and W. Mavhu. 2005. To Call or Not to Call a Spade a Spade: The Dilemma of Treating 'Offensive' Terms in Duramazwi Guru reChiShona. Lexikos 15: 253-264.

Fasold, R. 1987. The Sociolinguistics of Society. Oxford: Blackwell.

Fasold, R. 1993. The Sociolinguistics of Language. Oxford: Blackwell. 
Fromkin, V. and R. Rodman. 1993³. An Introduction to Language. New York: Harcourt Brace Jovanovich College Publishers.

Gregerson, E.A. 1977. Language in Africa: An Introductory Survey. New York: Gordon and Beach.

Goodenough, W.H. 1974. Cultural Antropology and Linguistics. Hymes, D. 1974. Language in Culture and Society: 36-39. New York/Evanston/London: Harper and Row.

Hadebe, S. (Ed.). 2001. Isichazamazwi SesiNdebele. Harare: College Press.

Kunene, E.C.L. and J.G. Mulder. 1992. Linguistic Considerations of Some Cultural Attitudes in siSwati. Herbert, R.K. (Ed). 1992. Language and Society in Africa: The Theory and Practice of Sociolinguistics: 335-344. Johannesburg: Witwatersrand University Press.

Lippert, A. 1972. The Changing Images of Women as Viewed in Literature of English and French Speaking West Africa. Unpublished Ph.D. Thesis. Bloomington: Indiana University.

Nyathi, P. 2001. Traditional Ceremonies of AmaNdebele. Gweru: Mambo Press.

Pelling, J.N. 1971. A Practical Ndebele Dictionary. Revised Edition. Salisbury: Longman Rhodesia.

Pride, J.B. and J. Holmes (Eds.). 1986. Sociolinguistics: Selected Readings. Harmondsworth: Penguin Books.

Stein, J. (Ed.). 1988. Random House College Dictionary. Revised Edition. New York: Random House. 